\title{
Unemployment Insurance and Vulnerable Households During the COVID-19 Pandemic
}

\author{
Serdar Birinci, Economist
}

T he U.S. economy experienced an unprecedented rise in the number of weekly unemployment insurance (UI) claims. Between March and mid-May, the total number of UI claims was around 34 million, higher than the 23.5 million UI claims during the entire year of 2008 at the depth of the Great Recession.

Can workers endure job loss without an increase in unemployment insurance benefits?

In response to the significant rise in the number of unemployed, federal and state governments implemented several important changes to UI policy. One of these changes was a significant increase in the weekly UI benefit amount paid to the eligible unemployed. Prior to the pandemic, UI payments covered 40 to 50 percent of a worker's previous average labor earnings during a base period. ${ }^{1}$ On average, this implies a payment of around $\$ 400$ per week in UI benefits. During this pandemic crisis, the federal government now provides an additional $\$ 600$ per week for each UI recipient, which amounts to a UI payment of $\$ 1000$ per week during this period.

Can unemployed workers endure the negative effects of an income drop due to job loss by using their own resources without the need for such a large increase in UI benefit generosity? For example, if they have sufficiently large

\section{Distribution of Net Liquid Wealth to Monthly Labor Income}

liquid wealth, then they may not need the generous government transfers during their unemployment spell.

To answer this question, using individual-level data, I first calculate the net liquid wealth of each individual. Liquid wealth is given by the summation of financial liquid assets such as interest-earning financial assets in banking and other institutions, non-interest-earning checking accounts, equity in stocks and mutual funds, face value of U.S. savings bonds, and net vehicle equity. I then subtract the revolving debt amount on credit card balances from the liquid wealth to obtain the net liquid wealth of each individual. Finally, dividing this number by the monthly salary of the individual gives a ratio of net liquid wealth to labor income.

The table shows the distribution of the net liquid wealth to monthly labor income ratio across all workers and UI recipients upon job loss. The median value of 1.60 across all workers implies that the median worker has only 1.6 months of salary-equivalent net liquid wealth. For those who actually lose their jobs and take up UI benefits, the median unemployed person has only about half a month's worth of salary-equivalent net liquid wealth. This means that if government transfers are not generous, the unemployed has to find new employment within a month to maintain a similar standard of living.

Furthermore, more than one-third of UI recipients have non-positive net liquid wealth, implying that their credit card debt is larger than any liquid wealth they may hold. ${ }^{2}$

Percentiles

\begin{tabular}{lcccccc} 
& 10th & 25th & 50th & 75th & 90th & $\begin{array}{c}\text { Fraction with } \\
\text { non-positive net liquid wealth }\end{array}$ \\
\hline All workers & -2.14 & 0.00 & 1.60 & 5.08 & 14.14 & 0.27 \\
Ul recipients & -2.34 & -0.34 & 0.42 & 1.73 & 7.80 & 0.36
\end{tabular}

NOTE: SIPP 2006. Detailed explanations are given in Birinci and See (2020). 


\section{ECONOMIC Synopses}

From these results we can conclude that unemployed individuals do not possess enough wealth to insure against even short spells of joblessness. This may point to the need for generous levels of UI benefits especially when labor markets do not function at their potential.

In conclusion, the recent increase in the UI benefit amount is needed by many of the unemployed because they do not own much liquid wealth to cope with the negative effects of job loss.

\section{Notes}

1 The base period is typically defined as the first four of the past five completed calendar quarters preceding the applicant's claim for UI benefits.

2 These results are calculated by the author and Kurt See using Survey of Income and Program Participation (SIPP) data for the year 2006. Detailed explanations can be found in Birinci and See (2020).

\section{Reference}

Birinci, Serdar, and See, Kurt Gerrard. "How Should Unemployment Insurance Vary over the Business Cycle?" Federal Reserve Bank of St. Louis Working Paper No. 2019-022C, February 2020;

https://research.stlouisfed.org/wp/more/2019-022. 